\title{
The 2014 coral bleaching and freshwater flood events in Kāne'ohe Bay, Hawai'i
}

Keisha D Bahr, Paul L Jokiel, Ku’ulei S Rodgers

Until recently, subtropical Hawai'i escaped the major bleaching events that have devastated many tropical regions, but the continued increases in global long-term mean temperatures and the apparent ending of the Pacific Decadal Oscillation (PDO) cool phase have increased the risk of bleaching events. Climate models and observations predict that bleaching in Hawai'i will occur with increasing frequency and increasing severity over future decades. A freshwater "kill" event occurred during July 2014 in the northern part of Kāne'ohe bay that reduced coral cover by $22.5 \%$ in the area directly impacted by flooding. A subsequent major bleaching event during Sept 2014 caused extensive coral bleaching and mortality throughout the bay and further reduced coral cover in the freshwater "kill" area by $60.0 \%$. The high temperature bleaching event only caused a $1.0 \%$ reduction in live coral throughout the portion of the bay not directly impacted by the freshwater event. Thus the combined impact of the low salinity event and the thermal bleaching event appears to be more than simply additive. The temperature regime during the Sept 2014 bleaching event was analogous in duration and intensity to that of the large bleaching event that occurred previously during Aug 1996, but resulted in a much larger area of bleaching and coral mortality. Apparently seasonal timing as well as duration and magnitude of heating is important. Coral spawning in the dominant coral species occurs early in the summer, so reservoirs of stored lipid in the corals had been depleted by spawning prior to the Sept 2014 event. Warm months above $27^{\circ} \mathrm{C}$ result in lower coral growth and presumably could further decrease lipid reserves, leading to a bleaching event that was more severe than would have happened if the high temperatures occurred earlier in the summer. Hawaiian reef corals decrease skeletal growth at temperatures above $27^{\circ} \mathrm{C}$, so perhaps the "stress period" actually started long before the bleaching threshold of $29^{\circ} \mathrm{C}$ was reached. Hawai'i is directly influenced by the PDO which may become a factor influencing bleaching events in subtropical Hawai'i in much the same manner as variations in the El Niño Southern Oscillation (ENSO) influences bleaching events at low latitudes in the tropical Pacific. Records show that offshore temperatures measured by satellite will not always predict inshore bleaching because other factors (high cloud cover, high wind and wave action, tidal exchange rate) can limit inshore heating and prevent temperatures in 
the bay from reaching the bleaching threshold. Low light levels due to cloud cover or high turbidity can also serve to prevent bleaching. 
1 Title: The 2014 coral bleaching and freshwater flood events in Kāne 'ohe Bay, Hawai' $i$

2

3 Authors: Keisha D. Bahr, Paul L. Jokiel, Ku'ulei S. Rodgers

4

5 Institute: Hawai'i Institute of Marine Biology

$6 \quad$ P.O. Box 1346

7 Kāne'ohe HI 96744 


\section{Introduction}

Coral bleaching is a stress response that results in the degeneration and expulsion of symbiotic algae known as zooxanthellae from the coral host (Douglas, 2003). As a result, the white skeleton becomes visible through the transparent coral tissue giving the organism a "bleached" white appearance. Bleaching is a highly subjective term used to describe a variety of conditions pertaining to low symbiont densities or loss of photosynthetic pigments of the algal symbionts (reviewed by Fitt et al., 2001; Jokiel, 2004) and not a simple direct response to elevated sea surface temperatures (SST). Local and global abiotic (e.g., irradiance, salinity, ultraviolet radiation, etc.) and biotic (e.g., disease) stressors may act alone or in combination to cause bleaching (reviewed in Jokiel 2004). The zooxanthellae provide photosynthetic products vital to meeting host energetic requirements (Falkowski et al., 1984). Bleached reef corals cannot survive very long unless conditions change and the symbiosis is reestablished (Baker, 2001); however, in severe cases high mortality occurs among the bleached corals (e.g. Wilkinson et al., 1999). Chronic or widespread loss of symbionts disturbs the metabolism of the coral host and can lead to delayed or reduced reproduction, tissue degradation, reduced growth, and death of the affected tissue (Michalek-Wagner \& Willis 2001; Szmant \& Gassman 1990; Williams \& Bunkley-Williams, 1990).

Since the 1980s, regional bleaching events have occurred on coral reefs throughout the world with increasing frequency and increasing geographic extent. The first massive bleaching event off Panama in 1983 was followed by more frequent and severe events throughout the world (Glynn, 1991; Graham, 1994). One of the largest mass bleaching events occurred in the Seychelles in 1998 where more than $90 \%$ of live coral cover was lost (Wilkinson et al., 1999). In the Caribbean in 2005, another mass bleaching event affected $80 \%$ of the coral reefs and over $40 \%$ of corals died at many locations across 22 countries (Eakin et al., 2009). The occurrence and severity of mass coral bleaching has increased continuously over the last two decades. As a result, almost every reef region in the world has now suffered extensive stress or coral mortality.

These large-scale bleaching events correlate with elevated sea surface temperatures (SST), especially during El Niño Southern Oscillation (ENSO) (Williams \& Bunkley-Williams, 1990; Glynn 1991; Wellington et al., 2001). However, major bleaching events have also occurred outside of ENSO periods (Brown, 1997). The increase in SST has been shown to be the result of climate change due to anthropogenic release of carbon dioxide and other gasses (HoeghGuldberg et al., 2007).

Until recently, the isolated subtropical location of Hawai' $i$ served as a haven from conditions that have ravaged coral reef communities in other areas of the world. The gradual rise in ocean temperature off Hawai'i shown in long-term records led Jokiel \& Coles (1990) to predict that Hawaiian reefs were also approaching their upper thermal limits and that the first bleaching events were imminent. The first large-scale bleaching event in the Hawai ' ${ }^{\prime}$ region occurred during the late summer of 1996 and was monitored closely in Kāne'ohe Bay throughout the period of onset, bleaching and recovery (Jokiel \& Brown, 2004). This event also impacted the northern part of the main Hawaiian Islands, while the majority of the Northwestern Hawaiian Islands (NWHI) showed no warming. In contrast, a second bleaching event during the summer of 2002 showed positive anomalies in the Northwest Hawaiian Islands (NWHI) and cool 
54

conditions in the main Hawaiian Islands (Brainard, 2002; Aeby et al., 2003). In 2013, an apparent shifting of the Pacific Decadal Oscillation (PDO) out of the cool phase and into the warm phase led Rodgers et al., (2015) to conclude that another bleaching event was imminent.

The PDO index is an empirical orthogonal function (EOF) of monthly sea surface temperature anomalies over the North Pacific poleward of $20^{\circ} \mathrm{N}$, calculated after the global mean SST has been removed (Schneider \& Cornnuelle, 2005). The monthly mean global average SST anomalies are removed to separate the Pacific pattern of variability from any "global warming" signal that may be present in the data. Monthly values since 1900 are reported at http://research.jisao.washington.edu/pdo/PDO.latest. The PDO has been described as a longlived ENSO-like pattern of Pacific climate variability (Zhang et al., 1997). The PDO is a climate phenomenon of the North Pacific (as opposed to ENSO which affects the tropical Pacific). The PDO typically alternates between two phases, but remains in each phase for a significant period of time (10 - 40 years). The two phases of the PDO have been called warm phases (positive values) or cool phases (negative values). The global SST pattern shows the strong tendency for temperatures in Hawai'i and the central North Pacific to be anomalously cool when SSTs along the coast of North America are unusually warm, and vice-versa (Graham, 1994; Zhang et al., 1997; Mantua et al., 1997). During the past century, two major PDO eras that persisted for 20 to 30 years have been identified (Mantua et al., 1997; Minobe, 1997). Cool PDO regimes prevailed from 1890-1924 and again from 1947-1976, while warm PDO regimes occurred from 1925-1946 and from 1977 through the mid-1990's.

Coral reefs are vulnerable to storm flooding events that reduce salinity in shallow waters (Banner 1968; Jokiel et al. 1993). Flash floods are intense, short in duration and common in Hawai'i. The humid air usually contains enough water to produce heavy rains at any time, but normally flash floods are associated with upper-level forcing (Jokiel, 2006). Flooding often occurs when convective cells are formed or enhanced by orographic effects and become anchored against high-vertical relief features. These conditions occurred during the night of 19 July 2014 in the Ko'olau Mountains at the head of the Wai'āhole - Waikāne valley watershed. The resulting flash floodwaters drained onto inshore reefs in the northern part of Kāne'ohe Bay. Reef corals can live under natural conditions at salinity ranging from $25-42 \%$ (Coles \& Jokiel, 1992). Reduction in salinity to $15-20 \%$ for a $24 \mathrm{~h}$ period or longer produce a lethal osmotic environment for the corals and their endosymbionts (Mayfield \& Gates, 2007). Such low salinities result in extensive bleaching and high mortality (Coles \& Jokiel, 1992; Jokiel et al., 1993). Freshwater flood events have been documented in Kāne'ohe Bay, Hawai'i during May 1965 (Banner, 1968), again during 1988 (Jokiel et al. 1993) and recently the more localized event occurred during flash floods in July 2014 (Bahr et al., 2015a) for a frequency of re-occurrence of approximately 25 years. During the 1965 flood, the freshwater discharged into the bay in a $24 \mathrm{~h}$ period was calculated to be equivalent to a surface layer of $27 \mathrm{~cm}$ over the entire bay (Banner, 1968). The reduction in salinity in surface waters caused massive mortality of coral reef organisms, with near total mortality of corals to a depth of 1-2 $\mathrm{m}$ in the inshore regions. Twenty-three years later, a comparable storm flood resulted in similar large-scale destruction of the reef flat corals in shallow $(<2 \mathrm{~m})$ water (Jokiel et al. 1993). Data on the frequency and intensity of these events are important in the understanding of long-term trends in coral reef ecology (Rodgers et al., 2015). 
The 2014 flash flood and subsequent high temperature bleaching event provided an opportunity to test an observation that high temperature and low salinity have a synergistic negative effect on corals (Coles and Jokiel, 1978). In addition, this high temperature bleaching event in relation to a long-term temperature record taken offshore is relevant to hind cast information as well as projections that predict more severe and more frequent occurrences over time (Jokiel \& Brown, 2004; Buddemeier et al., 2008; Hoeke et al. 2011). The first reports of bleaching led us to the hypothesis that the 2014 bleaching event would be more severe than the previous 1996 event in Kāne'ohe Bay, and would have greater impact in the area previously damaged by the storm flood.

\section{Methods}

\section{Study Site Description}

Kāne'ohe Bay, located on the northeast coast of O'ahu, Hawai'i $\left(21^{\circ}, 28^{\prime} \mathrm{N} ; 157^{\circ} 48^{\prime} \mathrm{W}\right)$, is a shallow ( $>50 \%$ of the bay is less than $3.3 \mathrm{~m}$ ) embayment and receives drainage from nine watersheds. It is the largest sheltered body of water in the eight main Hawaiian Islands with a total surface area of $41.4 \mathrm{~km}^{2}$ at mean surface levels (Jokiel, 1991; Bahr et al., 2015b). The bay contains numerous patch reefs and is bounded by a barrier reef on the seaward side creating restricted water exchange with the open ocean (Fig. 1). Also, most of the shoreline is ringed by shallow fringing reef 0.3-0.9 m deep (Jokiel, 1991; Bahr et al., 2015b). Due to restricted circulation in this bay the temperatures are historically $1-2^{\circ} \mathrm{C}$ higher than the open ocean in the summer months. Consequently, the corals in the bay are already living at temperatures that offshore ocean reefs will not experience for many years under various scenarios of global warming (Buddemeier et al., 2008; Bahr et al., 2015b).

Hawaiian waters contain about 40 coral species from eight families, of which only a few species are abundant (Maragos, 1972; Bahr et al., 2015b). Circulation patterns and environmental conditions control the distribution and abundance of coral species in the bay (Smith et al., 1981); however, historical anthropogenic influences (e.g., nutrient enrichment, dredging, and urbanization) have reduced coral coverage in the south bay (detailed in Bahr et al., 2015b). Corals in Kāne'ohe Bay are most commonly found on the reef crests and slopes of the fringing and patch reefs (summarized in Smith et al., 1973; Jokiel, 1991). The seaward portion of the barrier reef contains a lower percentage of live coral cover averaging about 5-10\%, most of which are high wave energy coral species (e.g., Pocillopora meandrina and Porites lobata). Coral cover in the landward lagoon waters ranges between $30-90 \%$, which is among the highest in the main Hawaiian Islands (Smith et al., 1981; Rodgers et al., 2015). The dominant corals Montipora capitata and the Hawaiian endemic species, Porites compressa, comprise $\sim 90 \%$ of the coral coverage in Kāne' ohe Bay (Edmondson, 1928; Maragos, 1972; Jokiel, 1991). Other abundant species include Pocillopora damicornis, Leptastrea purpurea, Porites lobata, and Fungia scutaria. A total of 22 species of coral are now protected under the Endangered Species Act, but none are found in Hawaii (NOAA, 2014). Surveys and assessments of this research were conducted under the Hawai' $i$ Institute of Marine Biology Special Acitivity Permit 2015-7.

\section{Surveys}

Freshwater Kill 
144 The freshwater event occurred during the night of 19 July 2014. The extent of the area damaged

145 by reduced salinity was determined on 25 July 2014 based on observations of dead organisms as

146 well as salinity measurements (YSI, model number 85-25FT) (Video S1) among the northern

147 leeward patch and fringing reefs in close proximity to stream mouths (Fig. 1). The initial

148 quantitative impact assessment of the freshwater event was conducted on 20 August 2014. On

149 patch reef 37 , five $25 \mathrm{~m}$ transects were strategically placed to include the reef flat on the north,

150 south, east, and west facing sides of the reef in addition to a central transect deployed parallel to

151 shore (Fig. 1). GPS locations were taken at the beginning and end of each transect using a

152 Garmin GPSMAP 76. These sites were also temporarily marked with rebar and color-coded

153 cable ties to allow for transect identification during resurveys. Benthic coral cover was

154 determined using high resolution digital images taken along each $25 \mathrm{~m}$ transect using a Canon

155 G12 zoom digital camera with an Canon WP-DC34 underwater housing. The camera was

156 mounted to an aluminum monopod frame, $73 \mathrm{~cm}$ from the substrate to provide a $50 \mathrm{~cm} \times 69 \mathrm{~cm}$

157 image. The 50 high resolution non-overlapping images from each $25 \mathrm{~m}$ transect were imported

158 into an ecological analysis program PhotoGrid (Bird, 2001) where 25 randomly selected points

159 were projected onto each image for a total of 1,250 points per transect. Relative abundance and

160 composition of benthic organisms and substrate were quantified including individual coral

161 species, higher taxonomic algal functional groups (e.g., coralline algae, turf, macro, etc.) and

162 abiotic substrate. Coral recovery surveys were conducted on 20 February 2015 on the same

163 transects.

164

165

166

167

\section{Bleaching Event}

Broad scale surveys were conducted on 14 October 2014 to determine the severity, extent, and spatial patterns of bleaching on the fringing, patch, and barrier reefs in Kāne' ohe Bay ( $\mathrm{n}=144$ sites). Rapid assessments of coral cover by species and condition at all sites were conducted by a vessel operator and tender (KS Rodgers), navigator and data recorder (KD Bahr) and surveyor (PL Jokiel). The visual estimate technique was conducted in clear calm conditions from the surface through a look box and/or snorkeling along the reef edge and across reef flats within a 5 minute observation period generally covering a swath of $25 \mathrm{~m}$ in length and $4 \mathrm{~m}$ in width. This method has been evaluated and quantitatively compared to eight other methods (i.e., quadrat, random, point intercept transect, CRAMP RAT, video transect, towed-diver, photographic transect, NOAA ground truth) and produces results comparable to techniques that require much more effort (Jokiel et al., 2015). The visual estimate technique is very rapid (5 minutes per transect) but consequently shows higher variance and requires an observer with extensive experience in quantitative assessments of coral cover and condition (Jokiel et al., 2015). Through this technique, we were able to evaluated bleaching severity and extent across the large sampling area and reduce variance by using the same experienced observer (PL Jokiel) at all sites. Moreover, the large number of sites increases confidence in the results. Coral condition was classified visually as "bleached" (pure white), "pale" (obvious pigment loss but some color), "normal" and newly "dead" skeleton using the same methodology and classification originally established by Jokiel \& Coles (1974). Estimates were made in the areas of high coral cover at a depth of 1-2 m. Subsequently, coral recovery surveys occurred on 1 December 2014 to assess coral mortality and pigmentation on the same reefs throughout the bay ( $\mathrm{n}=120$ sites) using the same methods and observer.

\section{Analysis of Historical Sea Water Temperature (SST) and Meteorological Data}


190 Offshore SST records based on satellite and other data at weekly intervals on a one-degree

191 latitude-longitude grid were obtained from the Integrated Global Ocean Services System

192 (IGOSS) at the International Research Institute for Climate and Prediction (IRI) website. These

193 data are produced at the US National Meteorological Center (NMC) using optimum interpolation

194 (OI) analysis of SST fields blended from ship, buoy and bias-corrected satellite data. Where

195 satellite data are used they are adjusted for biases using the method of Reynolds (1988) and

196 Reynolds \& Marsico (1993). A description of the OI analysis can be found in Reynolds \& Smith

197 (1994). Reynolds (1993) gives examples of the effect of recent corrections. The IGOSS-NMC

198 data sets were analyzed for the time period from November 1981 through December 2014. The

199 data set for $21-22^{\circ} \mathrm{N}, 157-158^{\circ} \mathrm{W}$ covers all waters offshore off east $\mathrm{O}^{`}$ ahu. Weekly IGOSS-

200 NMC temperature plots and temperature anomaly plots for the Hawaiian region $\left(16-33^{\circ} \mathrm{N}, 150\right.$ -

$201180^{\circ} \mathrm{W}$ ) were also analyzed (Fig. 4).

202

203

204

205

206

207

208

209

210

211

212

213

214

215

216

217

218

219

220

221

222

223

224

225

226

227

228

229

230

231

232

233

234

235

A 47-year time series of twice weekly SST taken at Koko Head on O`ahu, Hawai'i was developed by the National Marine Fisheries Service (NMFS) from 1955-1992. The sampling site was located along the steep cliffs that extend into deep water at $21^{\circ} 17^{\prime} \mathrm{N} ; 157^{\circ} 41^{\prime} \mathrm{W}$. SST at this location is representative of offshore central Pacific surface waters due to deep-water exposure and strong onshore currents (Seckel \& Yong, 1977). The IGOSS-NMC and the NMFS time series overlap between 1 Nov 1981 and 19 March 1992. An analysis of temperature records from the two sources during the overlap period determined the legitimacy of combining the NMFS and IGOSS-NMC data into a single record (Jokiel \& Brown, 2004). Mean summer monthly temperature in the Hawaiian region is approximately $27^{\circ} \mathrm{C} \pm 1^{\circ} \mathrm{C}$ (Jokiel \& Coles, 1977). A 30day exposure to temperatures of only $29-30^{\circ} \mathrm{C}$ will cause extensive bleaching in Hawaiian corals (Jokiel \& Coles, 1990).

Meteorological variables, irradiance and temperature in Kāne'ohe Bay were monitored throughout the bleaching events of 1996 and 2014 by an automatic recording weather station located on Moku o Lo'e at the Hawai'i Institute of Marine Biology (HIMB) (Fig. 1). Continuous water temperature was recorded at 1-2 $\mathrm{m}$ depth at three locations in the bay during the 2014 bleaching event: 1) fore reef slope of the Moku o Lo'e Reef in an area of high coral cover adjacent to the weather station (Fig 1. blue star), 2) back reef of Moku o Lo'e Reef at the NOAA National Ocean Service (Station ID 1612480, sensor E1, 1.2m depth) in a sheltered area near a well-developed coral community (Fig 1. red star), and 3) among corals in shallow water on "patch reef 37" in the northern part of the bay (Fig 1. black star). Temperature at the HIMB weather station was recorded using a recording thermistor thermometer (Cole-Parmer Instrument Co., Vernon Hills, IL, USA). Temperatures on patch reef 37 were collected with an Onset HOBO Pendant (UA-002-08) recording at 10 minutes intervals.

\section{Statistical Analysis}

The long term Koko Head temperature trends between 1956 and 2014 were analyzed using a linear regression and mean sea surface temperatures were analyzed with a One way ANOVA. Assumptions of normally distributed residuals and homoscedasticity were assessed through graphical analyses of the residuals. Detailed transect surveys were analyzed using a paired t-test. All statistical analyses were processed using JMP Pro 11 software (SAS Institute Inc., USA).

\section{$\underline{\text { Results }}$}


280 Extensive bleaching was first recorded on 21 September 2014 (Neilson, 2014). Massive

\section{Freshwater Event}

Previous freshwater storm events in Kāne'ohe Bay in 1965 (Banner, 1968) and in 1988 (Jokiel et al., 1993) killed shallow water corals throughout the bay. In contrast, the event on 20 July 2014 was restricted to northern patch and fringing reefs located in close proximity to Wai'āhole and Waikāne stream mouths (Fig. 1). Within a $24 \mathrm{~h}$ period, $24 \mathrm{~cm}$ of rainfall was measured at the Wai āhole rain gauge which increased the stream daily mean discharge by an order of a magnitude from $0.74 \mathrm{~m}^{3} \mathrm{~s}^{-1}$ to $24 \mathrm{~m}^{3} \mathrm{~s}^{-1}$ over a $48 \mathrm{~h}$ period (USGS, 2014). Hourly rainfall data during the event revealed the largest amount of rainfall $\left(4.1 \mathrm{~cm} \mathrm{~h}^{-1}\right)$ occurred at the lowest tide exposing those shallow reef communities to further reductions in salinity (Fig. S1). Temperatures prior to the storm event ranged from $27.4^{\circ} \mathrm{C}$ to $29.2^{\circ} \mathrm{C}$ on adjacent patch reefs. During the flood event the input of freshwater caused temperatures on the adjacent reef flat to decrease by $1^{\circ} \mathrm{C}$ and average irradiance levels deceased by $55 \%$. These low irradiance regimes persisted for three days following the event.

Extensive bleaching and mass mortality of corals and cryptic reef dwellers (e.g., eels, crabs, shrimp) were observed on more than $50 \%$ of the leeward surveyed patch and fringing reefs following the storm (Video S1). Coral tissues were killed and sloughed off and the dead skeletons were subsequently overgrown by turf algae. Of the major benthic substrate types surveyed, an increase was shown in all substrate types (i.e., macroalgae, turf, calcareous coralline algae, and silt) with the exception of coral cover between August 2014 and February 2015 (Fig. S2). On the surveyed patch reef 37, 22\% of total coral cover died as the direct result of the freshwater event.

\section{Bleaching Event}

Broad-scale Bleaching Surveys

Extreme warming occurred offshore of Hawai' $i$ during August-September 2014, leading NOAA (coralreefwatch.noaa.gov) to issue a bleaching warning in early Sept 2014 for the island of $\mathrm{O}^{\prime}$ ahu. Notifications gradually increased to a full bleaching alert later in the month. Reports of bleaching throughout Hawai' $i$ followed. By early September mean SST in Kāne'ohe Bay reached $28.5^{\circ} \mathrm{C}$ and was increasing rapidly (Fig. 2). Corals throughout the bay began to show signs of stress including contracted polyps, mucous secretion and some discoloration (Video S2). The maximum daily temperatures reached $30^{\circ} \mathrm{C}$ for nearly two weeks with maximum temperatures that exceed $30^{\circ} \mathrm{C}$ during mid-day on the reef flat (Fig. 2). By the middle of September, mid-day hourly water temperatures on the reef flat exceeded $31^{\circ} \mathrm{C}$. The conditions of low winds, high solar input, and increase in SST had a significant influence on the severity and extent of coral bleaching in the bay (Fig. 1).

Water temperatures at depth of less than $1 \mathrm{~m}$ on reef flat (solid black line for patch reef 37), depth of 1 to $2 \mathrm{~m}$ on reef slope (dashed blue line for HIMB weather station) and on the back reef at 1 to $2 \mathrm{~m}$ depth (solid red line for NOAA tide gauge station) during the 2014 bleaching event 20 August 2014 to 1 Dec 2014. Color of lines matches the color of the stars marking the respective location of each measurement site as plotted in Figure 1. bleaching (80-100\% of total coral cover) was observed in some areas (Fig. 3). High levels of 
282

283

284

285

286

287

288

289

290

291

292

293

294

295

296

297

298

299

300

301

302

303

304

305

306

307

308

309

310

311

312

313

314

315

316

317

318

319

320

321

322

323

324

325

326

327

bleaching and paling were observed throughout the bay. In the north bay, $73 \%$ of surveyed corals showed signs of bleaching and paling. Surveyed corals in the central and south bay also had high levels of bleaching and paling (62\%, 70\% respectively) (Fig. 3). On the barrier reef, where the total coral cover is low (5-10\%), 72\% of surveyed corals exhibited signs of bleaching (Fig. 3). Bleaching was observed to decrease with depth, especially in localized areas of high turbidity.

Relative bleaching sensitivity observed in Sept 2014 was similar to that reported for the Aug 1996 bleaching event, with members of the Pocilloporidae family as the most susceptible to bleaching. However, during the Sept 2014 event, colonies of Montipora capitata showed varied bleaching responses and were often more resistant to bleaching in comparison to the hardy Porites compressa. Additionally, we observed bleaching variations within species, where colonies in the same environment and often right to each other, showed different pigmentation levels.

Recovery of pigmentation was observed in early December 2014 in most of the bay except on the barrier reef where pigment loss was still prevalent (26\%) (Fig. 3). A large portion of the surveyed patch reefs were observed to recover in the north bay $(75 \%)$, south bay $(91 \%)$ and the central bay (89\%) (Fig. 3). Coral mortality levels were estimated to be less than 2\% in Aug 1996 (Jokiel \& Brown, 2004), while bay wide surveys indicated average coral mortality to reach 9\% following the 2014 freshwater kill and bleaching events combined (Table 1). Major mortality was largely confined to those reef areas impacted by the freshwater event, reaching nearly $60 \%$ following the bleaching event, while the reefs areas not influenced by the lowered salinity event only experienced 1\% bleaching mortality (Fig. 3; Table 1).

Detailed transect surveys indicated an additional significant decline in coral cover of $29.6 \%$ between August 2014 and February 2015 (paired t-test; $t_{(4)}=3.27, p=0.031$ ). The increased temperatures in late September exacerbated mortality of those corals exposed to the preceding flooding event. Therefore, the surveyed areas exposed to the flood water experienced an overall 42\% decline in coral cover between August 2014 and February 2015. The two major species $M$. capitata and $P$. compressa continued to dominate the coral cover throughout the bay as they have in the past through previous environmental perturbations since quantitative measurements have been taken (e.g. see Smith et al. 1973, 1981; Rodgers et al. 2015; Bahr et al., 2015b). We observed high mortality in certain less abundant species, such as Pocillopora damicornis, as also described in the 1996 bleaching event (Jokiel \& Brown, 2004).

\section{Hind-casting using the HadISST data set}

Offshore temperature during the 1996 bleaching event showed an offshore maximum of $27.4^{\circ} \mathrm{C}$, with one month mean temperature exceeding $27.0^{\circ} \mathrm{C}$, which might be taken as the hind cast threshold for bleaching conditions in Kāne'ohe Bay. However, if we use this value as a bleaching threshold, severe bleaching should have occurred during 1968 (maximum $28.0^{\circ} \mathrm{C}$, with 4 months exceeding $27.0^{\circ} \mathrm{C}$ ) and $1974\left(27.8^{\circ} \mathrm{C}\right.$ with 3 months exceeding $\left.27.0^{\circ} \mathrm{C}\right)$. We can state with confidence that large-scale bleaching absolutely did not occur during the years 1968 and 1974. Extensive scientific observations were being made in Kāne'ohe Bay during that time by a number of scientists operating from HIMB at Moku o Lo'e with no reports of bleached corals. The classic initial research on coral bleaching was then being conducted in Kāne'ohe Bay (e.g. 
Jokiel \& Coles, 1974, Jokiel \& Coles, 1977; Coles et al., 1976) so certainly any bleaching would have been detected. Likewise, there were no other reports of coral bleaching from $\mathrm{O}^{\prime}$ ahu or any

\section{Forecasting using the HadISST data set.}

The longest accurate temperature record available for Hawaiian waters shown in Fig. 4. A linear regression of these data (1956-2014) shows a significant positive slope $\left(\mathrm{R}^{2}=0.04, \mathrm{~F}_{(1,4359)}=198.2\right.$, $\mathrm{p}<0.0001$ ) indicating a $0.02^{\circ} \mathrm{C}$ increase in the annual mean temperature each year and a $1.15^{\circ} \mathrm{C}$ increase over the past 58 years. Mean sea surface temperatures were significantly higher in 2014 $\left(25.5^{\circ} \mathrm{C}\right)$ in comparison to $1956\left(24.4^{\circ} \mathrm{C}\right)\left(\right.$ One way ANOVA; $\left.\mathrm{F}_{(1,102)}=30.1 ; \mathrm{p}<0.0001\right)$. The trend is expected to continue as global climate change continues unabated, and the bleaching threshold will be crossed more often as time continues with increasingly long and more severe exposure to high temperature in a manner consistent with climate models developed for the region (Buddemeier et al. 2008; Hoeke et al. 2011).

\section{Discussion}

Coral reefs of the world will be increasingly vulnerable to large-scale bleaching events as the observed trend of increasing ocean temperatures continues. There is widespread agreement that global warming due to the production of anthropogenic gasses and the "greenhouse effect" is responsible for large-scale thermal bleaching throughout the world (e.g. Pittock, 1999; HoeghGuldberg, 1999). The year 2014 ranks as Earth's warmest since the beginning of systematic temperature recordings in 1880, according to two separate analyses by National Aeronautics and Space Administration (NASA) and National Oceanic and Atmospheric Administration (NOAA) scientists (http://www.giss.nasa.gov/research/news/20150116/, last accessed on 10 Mar 2015). Dramatic increases have occurred in the energy stored within the ocean (which is $90 \%$ or more of the total "global warming" heat) in the 1998-2014 time period (http://www.nodc.noaa.gov/OC5/3M_HEAT_CONTENT/, last accessed on 10 Mar 2015), which may signal another round of mass coral bleaching around the world during 2015.

This study investigated the effects of the lowered salinity and thermal bleaching events on the corals in Kāne'ohe Bay during the summer of 2014. The freshwater kill event reduced coral cover by $22.5 \%$ in the area directly impacted by flooding. The subsequent major bleaching event during Sept 2014 caused extensive coral bleaching and $1.0 \%$ reduction in live coral throughout the portion of the bay not directly impacted by the freshwater event. Areas that were influenced both by the thermal and freshwater events were shown to have a $60.0 \%$ reduction in coral cover. Thus the combined impact of the low salinity event and the thermal bleaching event appears to be more than simply additive.

\section{Chronology and extent of the Hawaii bleaching events}

The 1996, 2002 and 2014 bleaching events in Hawai' $i$ were triggered by positive summer open ocean temperature anomalies exceeding $1^{\circ} \mathrm{C}$. Moreover, periods of low winds, high solar input, and mid-day water temperatures exceeding $30^{\circ} \mathrm{C}$ had a significant influence on the severity and extent of coral bleaching in Kāne'ohe Bay (Fig. 2, 3). Observations made during the 1996 and 2014 events reinforce the role of high irradiance in accelerating bleaching of corals (Jokiel \& 
373 Brown, 2004), suggesting that corals in high light environments may be more susceptible to

374 bleaching (K. Bahr, unpublished data).

375

376

377

378

379

380

381

382

383

384

385

386

387

388

389

390

391

392

393

394

395

396

397

398

399

400

401

402

403

404

405

406

407

408

409

410

411

412

413

414

415

416

417 Global warming has impacted corals in various regions. Maynard et al. 2015 summarized
418 available information and report that bacterial, fungal and protozoan diseases of corals,

418

Previous laboratory and field studies have shown Hawaiian reef corals to experience physiological stress and decrease skeletal growth above $27^{\circ} \mathrm{C}$ with a bleaching threshold of 29$30^{\circ} \mathrm{C}$ (Jokiel \& Coles 1977, 1990), so perhaps the "stress period" actually starts when seawater temperature on the reef exceeds $27^{\circ} \mathrm{C}$. Temperatures exceeded $27^{\circ} \mathrm{C}$ for four weeks prior to bleaching in Aug 1996 and persisted an additional two weeks before dropping below $27^{\circ} \mathrm{C}$ in mid-September. Another temperature peak occurred in early October 1996 prolonging but not increasing the severity of the event. These conditions persisted for an additional four weeks and subsided in mid-October. The 1996 bleaching event was restricted to the central and southern portions of the bay. In 2014 , temperatures exceed $27^{\circ} \mathrm{C}$ for three weeks prior to the recording of bleaching in mid-September. These temperatures persisted for five weeks and slowly dropped below $27^{\circ} \mathrm{C}$ in late October (Fig. 5). Bleaching occurred over a much greater area throughout the bay in 2014 and extended to the barrier reef (Fig. 1). Higher coral mortality levels in the Sept 2014 thermal bleaching event are attributed to the lowered salinity event because the reefs areas not influenced by the lowered salinity event only experienced $1 \%$ bleaching mortality (Fig. 3; Table 1). The two events were very similar in terms of magnitude and duration of thermal stress (Fig. 5), but the Sept 2014 event damaged a much greater area (Fig. 1). The 2014 bleaching event occurred later in the summer suggesting that seasonal timing as well as duration and magnitude of heating are important.

Coral spawning in the dominant species occurred earlier in the summer during 1996. The dominant species Porites compressa spawned following the new moon every month from June to Sept. The other dominant species Montipora capitata spawned after the full moon from May to Sept. Perhaps both species had used their reserves of lipid prior to the Sept 2014 bleaching event, which made them more vulnerable to the increased temperature. The subsequent warm months above $27^{\circ} \mathrm{C}$ result in lower growth and presumably further decreased lipid reserves, leading to a bleaching event that was more severe than would have happened if the high temperatures occurred earlier in the season.

During the Sept 2014 bleaching event, several colonies of M. capitata were observed to be more resistant to bleaching than $P$. compressa unlike the bleaching hierarchy described by Jokiel and Brown (2004) during the Aug 1996 event. Since then, hierarchical bleaching incidence and temperature tolerances by species have been reported for Hawaiian corals by Bahr (unpublished data, 2015) in manipulative mesocosm experiments and confirm these new observations. Also, bleaching was observed to be highly variable among individuals of the same species during the Sept 2014 event. These differences may be attributed to different physiological tolerance of the strains of Symbiodinium species and the coral hosts (Fitt and Warner, 1995; Warner et al., 1996; Kinzie III et al., 2001; Berkelmans \& van Oppen, 2006). Moreover, the spatial extent and patterns of bleaching responses may be influenced by factors that control the amount of solar radiation reaching the corals (i.e., cloud cover, turbidity, shading, depth) (Kirk, 1994; Brown, 1997; Mumby, 2001).

PeerJ reviewing PDF | (2015:06:5273:2:1:ACCEPTED 1 Jul 2015) 
419 (including black band disease, yellow band disease and white syndromes) are known to have 420 links to temperature. They developed climate models that project higher temperature conditions 421 to the increase the susceptibility of corals to disease, increased pathogen abundance and 422 virulence. Vibrios are ubiquitous in the aquatic environment with a high abundance of vibrios 423 detected in tissues and/or organs of many marine organisms such as algae, corals, fish, and 424 zooplankton. There are 74 species of this group are distributed among four different families 425 (Thompson et al. 2004). Vibrio spp. are frequently identified as pathogens of reef corals and have 426 been associated with bacterial bleaching (Kushmaro et al. 1996, Ben-Haim \& Rosenberg, 2002; 427 Weil et al., 2006; Rosenberg et al., 2007). Gregoracci et al. (2012) studied that bacterioplankton 428 diversity and abundance in a large tropical bay and found that higher nutrient input favored higher microbial growth including Vibrio spp. Thus, a rich and diverse population of vibrio is always present and nutrients brought into Kāne'ohe Bay by the flood event could have enhanced the growth of the vibrio disease during the following bleaching event. In fact, a disease outbreak in Kāne'ohe Bay was reported when the corals were beginning to recover from bleaching (Department of Land and Natural Resources, 2015), but this work is still in progress.

\section{Documenting the causes of the freshwater reef kill and predicting rate of recovery}

The presence of a major flash flood was documented by rain and stream gauges. Very cold water (i.e., stream water) measured by thermographs on the reef showed low temperature at time of maximum stream flow of very short and intense duration. Dead and dying organisms were found in shallow water $(<2 \mathrm{~m})$ only and deeper corals were not affected due to the less dense freshwater that formed a persistent surface layer. Also, there was a strong mortality gradient with a high percentage of dead and dying reef organisms near the stream mouth grading into undamaged reefs at a distance of approximately $1 \mathrm{~km}$ from the stream discharge point. Nutrients and sediment input that accompanied the flood appeared to have an influence on the increase in area covered by macroalgae, turf, and silt. We can rule out high temperature as a cause because the freshwater event occurred nearly a month before the first signs of bleaching were observed throughout Hawaii. Observations on the patterns of mortality in corals and other organisms (sea cucumbers, crabs and cryptic fish such as eels) are consistent with historical evidence described in Kāne'ohe Bay from two previous freshwater kill events (Banner, 1968; Jokiel et al., 1993). Rate of recovery in the area impacted is expected to be rapid based on this previous information. Recovery was delayed after the 1965 storm event in the south basin due to the presence of two major sewer outfalls, which led to macroalga overgrowth and anoxic conditions and prevented coral recovery. After sewage discharge was terminated in 1979 these reefs recovered rapidly as shown by surveys during 1985 (Hunter and Evans 1995). In contrast, the reef coral communities killed in the 1988 flood were not impacted by sewage and consequently recovered rapidly, with substantial increases in coral cover at 5 years and near complete recovery at 10 years (Jokiel et al. 1993). Comparison between recovery rates after the two flood events suggests that Kāne'ohe Bay coral reefs can recover quickly from natural flood disturbances, but not under chronic polluted conditions.

\section{Forecasting bleaching recovery}

Rates of bleaching recovery in Hawaiian corals is on the order of several months as shown by field studies (Jokiel \& Coles 1974) and laboratory studies (Jokiel \& Coles, 1977), but with 
465

466

467

468

469

470

471

472

473

474

475

476

477

478

479

480

481

482

483

484

485

486

487

488

489

490

491

492

493

494

495

496

497

498

499

500

501

502

503

504

505

506

507

508

509

510 accompanying rates of mortality depending on the extent and duration of the high temperature exposure (Jokiel, 2004). Recovery from the 1996 bleaching event was described by Jokiel and Brown (2004). Mortality rate was very low $(<2 \%)$ so the major recovery response was from bleached condition to normal pigmentation, which occurred completely among bleached corals within 6 months. The rapid recovery of Kāne'ohe Bay bleached corals observed in this study are consistent with previous findings. Due to the low mortality levels and high recovery rates observed in the Aug 1996, major phase shifts are not expected to occur as a result of the Sept 2014 bleaching event. Results of these studies suggest there is no justification for human intervention in the form of transplantation or seeding larvae. However, bleaching events in Kāne'ohe Bay are predicted to occur at much more frequent intervals with much greater mortality due to impending climate change with near elimination of Kāne 'ohe Bay corals by the end of the century (Buddemeier et al. 2008).

Pacific Decadal Oscillation (PDO) and bleaching events in Hawai ' $i$.

The long-term trend of increasing water temperature in Hawaiian waters (Fig. 4) originally led Jokiel and Coles (1990) to conclude that Hawai' $i$ was approaching the upper bleaching threshold for corals. The first documented bleaching event in Hawai'i occurred in 1996 (Jokiel \& Brown, 2004). However, there was a downward change in the temperature trend at the end of the 1997/98 ENSO (Fig. 4). Reefs in other parts of the world were severely impacted by the extreme 1998 ENSO and following events (Fig. S3), but Hawai'i reef escaped damage. After the 1998 event there was a slowing of the warming trend off Hawai' $i$ and what appears to be another small oscillation between the 1996 and 2014 bleaching events (Fig. 4). These changes are consistent with the findings of Fang et al. (2014). Their model suggests that the "North Pacific Ocean decadal variability, its dominant mode (i.e., PDO), and atmospheric decadal variability, have become weaker under global warming, but with PDO shifting to a higher frequency." The mean global temperature will continue to increase as humans add additional greenhouse gasses to the atmosphere. Entering the cool phase of the PDO initially slowed predicted increases in temperature for Hawaiian coral reefs, but much warmer conditions can be expected in Hawaiian waters as the PDO reverses into the warm phase with the PDO warming increments being added to the increasing global mean. The December 2014 PDO value hit a new all-time record level of +2.51 which is the highest and hottest PDO index value since record-keeping began in 1900 . The index continued to be very high into 2015 (http://research.jisao.washington.edu/pdo/PDO.latest, last accessed 1 May 2015 ). Perhaps the PDO fluctuations may become a major factor influencing future mass bleaching events in Hawai' $\mathrm{i}$, much as the patterns of ENSO influences bleaching events at lower latitudes.

\section{Bleaching in Hawai ' $i$ Compared to Other Geographic Regions}

The increase of approximately $1.15^{\circ} \mathrm{C}$ over the course of the 58 year record from Hawai' $\mathrm{i}$ (Fig. 4) translates into a $0.20^{\circ} \mathrm{C}$ increase per decade. This value falls within the $0.07^{\circ} \mathrm{C}$ to $0.5^{\circ} \mathrm{C}$ increase per decade range measured on various coral reefs throughout the world (summarized by Fitt et al., 2001). Monitoring of reefs throughout Hawai'i over the past 14 years (Rodgers et al., 2015) showed that overall coral cover and diversity in Hawai' $i$ have remained relatively stable since the initial survey in 1998. During this period, coral cover on reefs in the Caribbean and other regions declined by as much as $50 \%$ due to climate change related bleaching events, 
511 increased storm damage and lower coral growth (Wilkinson, 2004). Nevertheless, Hawai' $i$ is

512 now at a threshold of more severe and frequent bleaching events projected for the near future

513 (Jokiel \& Brown, 2004; Donner, 2009; Hoeke et al., 2011; Rodgers et al., 2015).

514

515

516

517

518

519

520

521

522

523

524

525

526

527

528

529

530

531

532

533

534

\section{Conclusions}

Increasing emissions of anthropogenic greenhouse gasses have resulted in global climate changes that include global warming as well as intensification of storm flood patterns. Results of this study reveal the combined impact of a lowered salinity event and the subsequent high temperature bleaching events caused a further reduction in coral cover. The influence of two of events operating in succession produced higher levels of coral mortality Kāne'ohe Bay. The temperature regimes during the Sept 2014 bleaching event were analogous to the Aug 1996 event in terms of duration and intensity, but a larger area of bleaching and coral mortality was observed. Therefore seasonal timing as well as duration and magnitude of high temperature events are important.

Until recently, subtropical Hawai' $i$ escaped the major bleaching events that have devastated many tropical regions around the world, but the continued increases in global long-term mean temperatures and the apparent ending of the Pacific Decadal Oscillation (PDO) cool phase have increased the risk of bleaching events in this area. Moreover, the PDO may become a factor influencing bleaching events in subtropical Hawai' $i$ in much the same manner as variations in the El Niño Southern Oscillation (ENSO) influences bleaching events at low latitudes in the tropical Pacific.

Records show that hindcasting using offshore temperatures measured by satellites will not always accurately predict inshore bleaching. It is known that other factors (cloud cover, wind and wave action, turbidity tidal exchange rate) can reduce high irradiance and limit heating in the nearshore environment and thereby prevent or reduce bleaching and mortality on coral reefs. Nonetheless, long term temperature records and documented bleaching events are consistent with the climate models and observations that predict more frequent and increasing severity of bleaching in Hawai' $i$ over future decades.

\section{Acknowledgments}

We would like to thank L. Van Heukelem, C. Westbrooke, C. Lager, K. Adams, M. Bargerhuff, E. Burns, E. Day, K. Giffen, C. Guo, S. Rodeghero, M. Russell, J. Sheu, R. Sirota, J. Streiffert, and A. Williams for their assistance in the documentation of the freshwater and bleaching event. We would also like to to thank two anonymous reviewers for their time, advice and comments which have helped improve the manuscript significantly. 
550

551

552

553

554

555

556

557

558

559

560

561

562

563

564

565

566

567

568

569

570

571

572

573

574

575

576

577

578

579

580

581

582

583

584

585

586

587

588

589

590

591

592

Aeby GS, Kenyon JC, Maragos JE, Potts DC. 2003. First record of mass coral bleaching in the Northwestern Hawaiian Islands. Coral Reefs 22:256.

Bahr KD, Rodgers KS, Jokiel PL. 2015a. Recent freshwater reef kill event in Kāne'ohe Bay, Hawai'i. Coral Reefs Reef Encounter 30(1):42.

Bahr, KD, Jokiel PL, Toonen RJ. 2015b. The unnatural history of Kāne'ohe Bay: Coral reef resilience in the face of centuries of anthropogenic impacts. PeerJ 3:e950

Baker AC. 2001. Reef corals bleach to survive change. Nature 411:765-766.

Banner AH. 1968. A freshwater "kill" on the coral reefs of Hawai' i. Hawai'i Institute of Marine Biological Technology Rep 15:1 29.

Ben-Haim Y, Rosenberg E. 2002. A novel Vibrio sp. pathogen of the coral Pocillopora damicornis. Marine Biology, 141(1), 47-55.

Berkelmans R, van Oppen MJH. 2006. The role of zooxanthellae in the thermal tolerance of corals: a 'nugget of hope' for coral reefs in an era of climate change. Proceedings of the Royal Society B. 273: 2305-2312.

Bird CE. 2001. PhotoGrid: Ecological Analysis of Digital Photographs (downloadable online software). University of Hawai'i, Honolulu, Hawai' $i$. http//www.photogrid.netfirm.com/.

Brainard R. 2002. Bleaching in NW Hawaiian Islands. Bleaching Report, National Environmental Satellite, Data, and Information Service. ORA/ORSPD Coral Reef Team, Coral Reef Bleaching Hotspots.

http://www.osdpd.noaa.gov/PSB/EPS/SST/data/als_bleaching.10.16.2002

Brown BE. 1997. Coral bleaching causes and consequences. Coral Reefs 16:S129-Sl38.

Buddemeier RW, Jokiel PL, Zimmerman KM, Lane DR, Carey JM, Bohling GC, Martinich JA. (2008) A modeling tool to evaluate regional coral reef responses to changes in climate and ocean chemistry. Limnology and Oceanography: Methods 6:395-411.

Coles SL, Jokiel PL. 1978. Synergistic effects of temperature, salinity and light on the hermatypic coral Montipora verrucosa (Lamarck). Marine Biology, 49:187-195.

Coles SL, Jokiel PL. 1992. Effects of salinity on coral reefs. In: D. W. Connell and D. W. Hawker (eds.) Pollution in Tropical Aquatic Systems. CRC Press, Inc. London pp. 170-191

Coles SL, Jokiel PL, Lewis CR. 1976. Thermal tolerance in tropical versus subtropical Pacific reef corals. Pacific Science 30:156-166.

Department of Land and Natural Resources. 2015. Corals at Kaneohe Bay now impacted by disease. http://dlnr.hawaii.gov/blog/2015/02/12/nr15-023/ (Last accessed on June 23, 2015).

Donner SD. 2009. Coping with commitment: projected thermal stress on coral reefs under different future scenarios. PLoS One 4:e5712.

Douglas, A.E. 2003. Coral bleaching - how and why? Marine Pollution Bulletin 46: 385-392.

Eakin CM, Lough JM, Heron SF. 2009. Climate variability and change: monitoring data and evidence for increased coral bleaching stress. In: van OppenM, Lough JM(eds) Coral bleaching: patterns, processes, causes and consequences. Springer, Heidelberg, pp 41-67.

Edmondson CH. 1928. The ecology of a Hawaiian coral reef. Bulletin 45. Bernice Pauahi Bishop Museum. 64 pp.

Falkowski PG, Dubinsky Z, Muscatine L, Porter JW. 1984. Light and the bioenergetics of a symbiotic coral. BioScience 34:705-709. 
593

Fitt WK, Warner ME. 1995. Bleaching patterns of four species of Caribbean reef corals. Biological Bulletin 189:298-307.

Fitt WK, Brown BE, Warner ME, Dunne RP. 2001. Coral bleaching: interpretation of thermal tolerance limits and thermal thresholds in tropical corals. Coral Reefs 20:51-65.

Glynn PW. 1991. Coral reef bleaching in the 1980s and possible connections with global warming. Trends in Ecology and Evolution 6:175-179.

Graham N.E. 1994. Decadal-scale climate variability in the 1970s and 1980s: observations and model results. Climate Dynamics, 10:135-159.

Gregoracci GB, Nascimento JR, Cabral AS, Paranhos R, Valentin JL, Thompson CC, Thompson FL. 2012. Structuring of bacterioplankton diversity in a large tropical bay. PloS one, $7(2)$, e31408.

Hoegh-Guldberg O. 1999. Climate change, coral bleaching and the future of the world's coral reefs. Marine and Freshwater Research 50:839-866.

Hoegh-Guldberg O, Mumby PJ, Hooten AJ, Steneck RS, Greenfield P, Gomez E, Harvell CD, Sale PF, Edwards AJ, Caldeira K, Knowlton N, Eakin CM, Iglesias-Prieto R, Muthiga N, Bradbury RH, Dubi A, Hatziolos ME. 2007. Coral reefs under rapid climate change and ocean acidification. Science 318 (5857): 1737-1742.

Hoeke RK, Jokiel PL, Buddemeier RW, Brainard RE. 2011. Projected changes to growth and mortality of Hawaiian corals over the next 100 years. PLoS One 6: e18038.doi:10.1371/journal.pone.0018038.

JMP, Version Pro 11. SAS Institute Inc., Cary, NC, 1989-2007.

Jokiel PL. 2004. Temperature stress and coral bleaching. p. 401-425. In: Coral Health and Disease (eds Rosenberg E and Loya Y). Springer-Verlag, Heidelberg.

Jokiel, PL. 2006. Impact of storm waves and storm floods on Hawaiian reefs. Proceedings of the Tenth International Coral Reef Symposium. pp 390-398.

Jokiel, PL, Brown EK. 2004. Global warming, regional trends and inshore environmental conditions influence coral bleaching in Hawai'i. Global Change Biology 10:1627-1641.

Jokiel PL, Coles SL. 1974. Effects of heated effluent on hermatypic corals at Kahe Point, Oahu. Pacific Science 28:1-18.

Jokiel PL, Coles SL. 1977. Effects of temperature on the mortality and growth of Hawaiian reef corals. Marine Biology 43:201-208.

Jokiel PL, Coles SL. 1990. Response of Hawaiian and other Indo-Pacific reef corals to elevated temperatures associated with global warming. Coral Reefs 8:155-162.

Jokiel PL, Hunter CL, Taguchi S, Watarai L. 1993. Ecological impact of a fresh water "reef kill" in Kāne'ohe Bay, Oahu, Hawai'i. Coral Reefs 12:177-184.

Jokiel PL, Rodgers KS, Brown EK, Kenyon JC, Aeby G, Smith WR, Farrell F. 2015. Comparison of methods used to estimate coral cover in the Hawaiian Islands. PeerJ 3:e954 https://dx.doi.org/10.7717/peerj.954.

Kinzie RA III, Takayama M, Cofforth MA. 2001. The adaptive bleaching hypothesis: experimental tests of critical assumptions. Biological Bulletin 200:51-8.

Kirk JTO. 1994. Light And Photosynthesis In Aquatic Ecosystems, 2nd Edition ed. Cambridge University Press.

Kushmaro A, Banin E, Loya Y, Stackebrandt E, Rosenberg E. 2001. Vibrio shiloi sp. nov., the causative agent of bleaching of the coral Oculina patagonica. International journal of systematic and evolutionary microbiology,51(4), 1383-1388 
639

640

641

642

643

644

645

646

647

648

649

650

651

652

653

654

655

656

657

658

659

660

661

662

663

664

665

666

667

668

669

670

671

672

673

674

675

676

677

678

679

680

681

682

683

Mantua NJ, Hare SR, Zhang Y, Wallace JM, Francis RC. 1997. A Pacific interdecadal climate oscillation with impacts on salmon production. Bulletin of the American Meteorological Society 78:1069-1079.

Maragos JE. 1972. A study of the ecology of Hawaiian reef corals. Ph.D. Thesis, University of Hawai'i, Honolulu. 290 pp.

Maynard J, van Hooidonk R, Mark Eakin C, Puotinen MP, Garren M,Williams G, Heron SF, Lamb J, Weil E, Willis B, Harvell CD. 2015. Projections of climate conditions that increase coral disease susceptibility and pathogen abundance and virulence. Nature Climate Change. doi:10.1038,NCLIMATE2625

Mayfield AB, Gates RD. 2007. Osmoregulation in anthozoan-dinoflagellate symbiosis. Comparative Biochemistry and Physiology Part A: Molecular \& Integrative Physiology. 147(1): 1-10.

Michalek-Wagner K, Willis BL. 2001. Impacts of bleaching on the soft coal Lobophytum compactum. I. Fecundity, fertilization and offspring viability. Coral Reefs 19:231-239.

Minobe S. 1997. A 50-70 year climatic oscillation over the North Pacific and North America. Geophysical Research Letters 24:683-686.

Mumby PJ, Chisholm JRM, Edwards AJ, Andrefouet S, Jaubert J. 2001. Cloudy weather may have saved Society Island reef corals during the 1998 ENSO event. Marine Ecology Progress Series 222:209-216.

Neilson B. 2014. Coral Bleaching Rapid Response Surveys September-October 2014. http://dlnr.Hawai'i.gov/reefresponse/files/2014/10/DARCoralBleachingSrvy_Results_10.28.2 014.pdf. (last accessed 26 June 2015).

NOAA 2014. NOAA lists 20 new corals as threatened under the Endangered Species Act. NOAA_Corals_Fact_Sheet_130115.pdf available at http://www.nmfs.noaa.gov/stories/2014/08/corals_listing.html, last accessed on 23 June 2015.

Pittock AB. 1999. Coral reefs and environmental change; adaptation to what? American Zoologist 39:10-29.

Reynolds RW. 1988. A real-time global sea surface temperature analysis. Journal of Climate 1: 75-86.

Reynolds RW. 1993. Impact of Mount Pinatubo aerosols on satellite-derived Sea Surface Temperatures. Journal of Climate 6:768-774.

Reynolds RW, Marsico DC. 1993. An improved real-time global sea surface temperature analysis. Journal of Climate 6:114-119.

Reynolds RW, Smith TM. 1994. Improved global sea surface temperature analyses. Journal of Climate 7:929-948.

Rodgers KS, Jokiel PL, Brown EK, Hau S, Sparks R. 2015. Over a decade of change in spatial and temporal dynamics of Hawaiian coral reef communities. Pacific Science 69(1):1 - 13.

Rosenberg E, Koren O, Reshef L, Efrony R, Zilber-Rosenberg I. 2007. The role of microorganisms in coral health, disease and evolution. Nature Reviews Microbiology, 5(5), 355-362.

Seckel GR, Yong MYY. 1977. Koko Head, Oahu, sea-surface temperatures and salinities, 19561973, and Christmas Island sea-surface temperatures, 1954-1973. Fisheries Bulletin 75:767787.

Schneider N, Cornuelle BD. 2005. The forcing of the Pacific Decadal Oscillation. Journal of Climate 18:4355-4373. 
684

685

686

687

688

689

690

691

692

693

694

695

696

697

698

699

700

701

702

703

704

705

706

707

708

709

710

Smith, SV, Chave KE, Kam DTO. 1973. Atlas of Kāne 'ohe Bay. University of Hawai'i Sea Grant Program Publication UNHI-SEAGRANT-TR-72-01, Honolulu 128 pp.

Smith SV, Laws EA Brock RE Walsh TW. 1981. Kāne`ohe Bay Sewage Diversion Experiment: Perspectives on ecosystem responses to nutritional perturbation. Pacific Science 35:297-396.

Szmant A, Gassman N. 1990. The effects of prolonged "bleaching" on the tissue biomass and reproduction of the reef coral Montastrea annularis. Coral Reefs $\mathbf{8}$ : 217-224.

Thompson FL, Iida T, Swings J. 2004. Biodiversity of vibrios.Microbiology and molecular biology reviews, 68(3), 403-431.

USGS. 2014. United States Geological Service National Water Information System. Online at http://waterdata.usgs.gov/nwis/rt.

Warner, ME, WK Fitt, GW Schmidt. 1996. The effects of elevated temperature on the photosynthetic efficiency of zooxanthellae in hospite from four different species of reef coral: a novel approach. Plant Cell Environment 19:291-299.

Wellington GM, Glynn PW, Strong AE, Nauarrete SA, Wieters E, Hubbard D. 2001. Crisis on coral reefs linked to climate change. Eos 82:1-7.

Wilkinson CR, Linden O, Cesar H, Hodgson G, Rubens J, Strong AE. 1999. Ecological and socio-economic impacts of 1998 coral mortality in the Indian Ocean: An ENSO impact and a warning of future change? Ambio 28:188-196.

Wilkinson CR. 2004. Status of Coral Reefs of the World: Global Coral Reef Monitoring Network \& Australian Institute of Marine Science, Townsville, 2:264 pp.

Williams EH Jr, Bunkley-Williams L. 1990. The world-wide coral reef bleaching cycle and related sources of coral mortality. Atoll Research Bulletin 335:1-71.

Weil E, Smith G, Gil-Agudelo DL. 2006. Status and progress in coral reef disease research. Diseases of Aquatic Organisms, 69(1), 1-7.

Zhang, Y., Wallace JM, Battisti DS.1997. ENSO-like interdecadal variability: 1900-93. Journal of Climate 10:1004-1020. 


\section{Table $\mathbf{1}$ (on next page)}

Broad-scale bleaching assessment

Percentage of surveyed corals classified as normal, pale, bleached, or dead in the freshwater impacted areas and non-impacted areas during the bleaching assessment (14 October 2014) and the recovery assessment (1 December 2014). 


\begin{tabular}{|c|c|c|c|c|c|c|c|}
\hline \multirow{2}{*}{$\begin{array}{c}\text { Proportion of } \\
\text { surveyed corals }\end{array}$} & \multicolumn{2}{|c|}{ 14 October 2014: Bleaching } & & \multicolumn{3}{|c|}{ 1 December 2014: Recovery } \\
\cline { 2 - 4 } & Impacted & Non-Impacted & Overall & & Impacted & Non-Impacted & Overall \\
\hline Total Coral Cover & 49.4 & 61 & 59.6 & & 53.6 & 54.9 & 63.2 \\
\hline Normal & 1.6 & 32.6 & 27.4 & & 33.1 & 90.2 & 82.4 \\
\hline Pale & 26.5 & 22.7 & 23 & & 4.1 & 6.3 & 6 \\
\hline Bleached & 49.4 & 44.7 & 45.3 & 2.8 & 2.6 & 2.6 \\
\hline Dead & 22.5 & 0 & 4.3 & & 60 & 0.9 & 9 \\
\hline
\end{tabular}


1

Bleaching events in Kāne'ohe Bay

Extent of impact in the 1996 (cross-hatch) and 2014 (gray) bleaching events in Kāne'ohe Bay, O'ahu Hawai'i. A) Enlarged photograph of O'ahu, Hawai'i. Kāne'ohe Bay is indicated by the white square. B) Impacted area from the proceeding freshwater event (July 2014) is indicated in the area bounded by the black square. Location of temperature recorders are shown on reef flat (black star), back reef (red star) and on reef slope (blue star). 


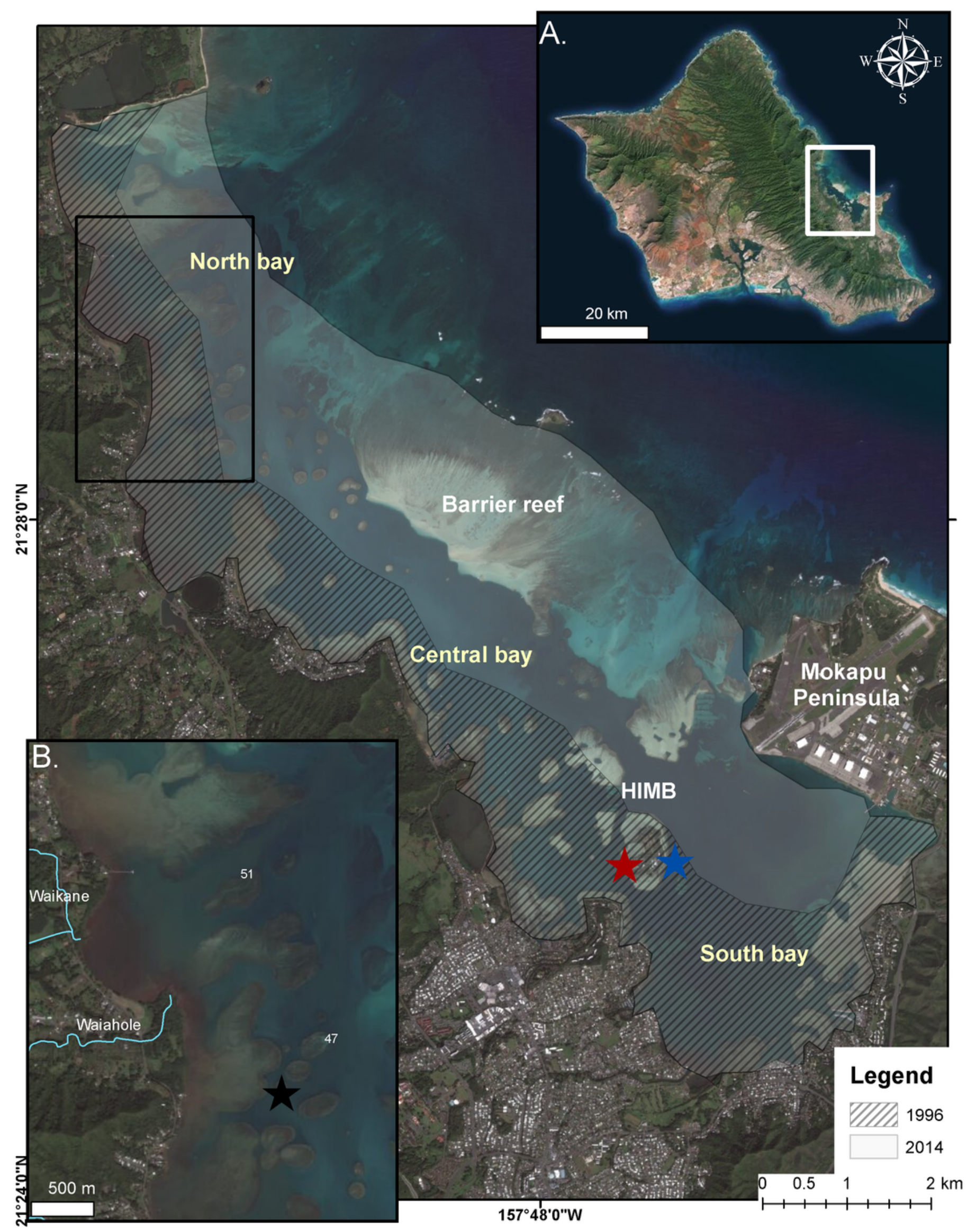


2

Variations in water temperatures in Kāne'ohe Bay at different reef locations

Water temperatures at depth of less than $1 \mathrm{~m}$ on reef flat (solid black line for patch reef 37), depth of 1 to $2 \mathrm{~m}$ on reef slope (dashed blue line for HIMB weather station) and on the back reef at 1 to $2 \mathrm{~m}$ depth (solid red line for NOAA tide gauge station) during the 2014 bleaching event 20 August 2014 to 1 Dec 2014. Color of lines matches the color of the stars marking the respective location of each measurement site as plotted in Figure 1.

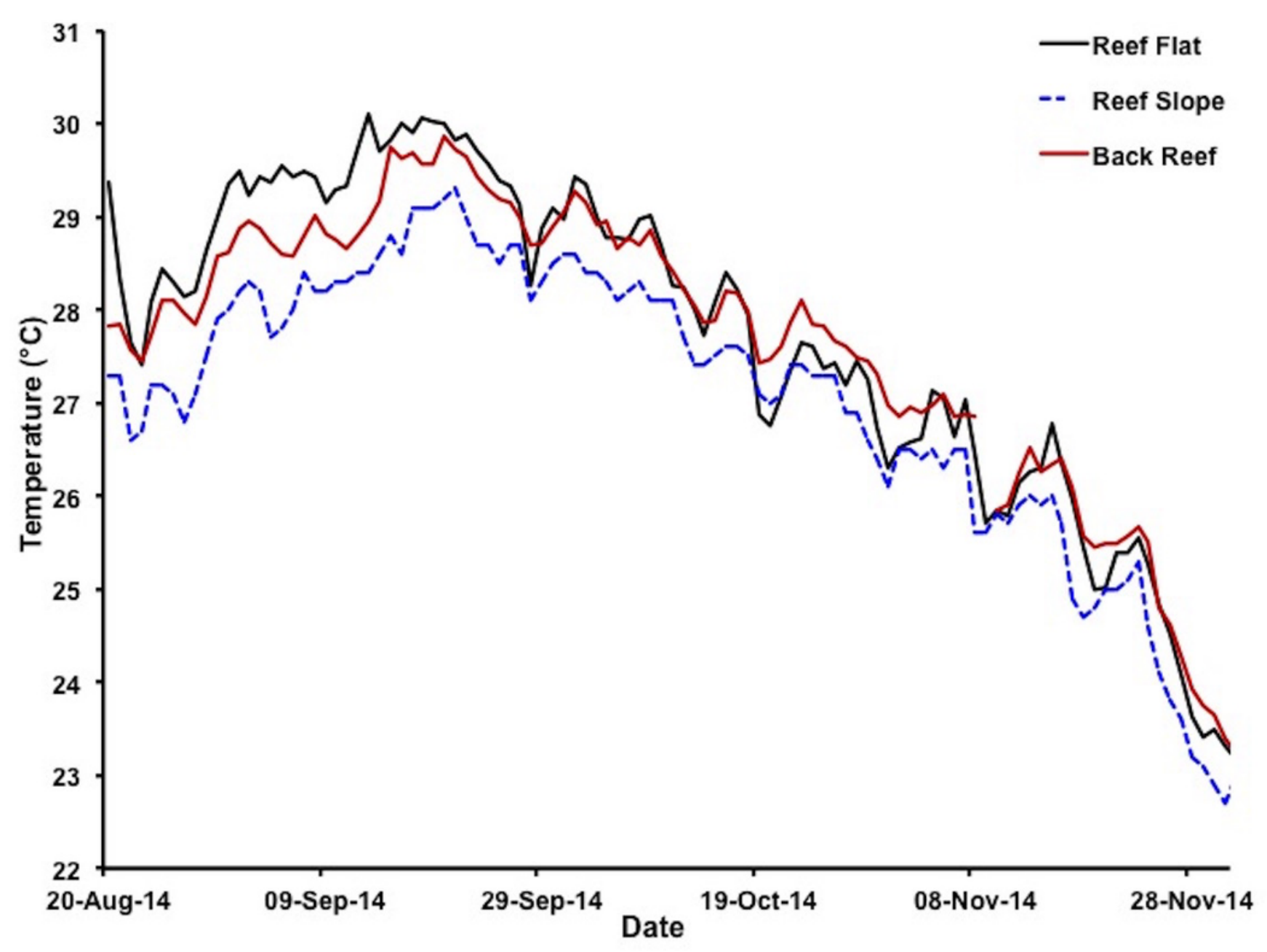




\section{3}

Extent of 2014 bleaching event

Surveyed sites during the bleaching event in Kāne'ohe Bay in October 2014 (A) and after initial recovery in December 2014 (B). Area impacted by the flooding event is indicated in the black square. Proportion of surveyed corals are shown as normal (red), pale (yellow), bleached (white), and dead (black).

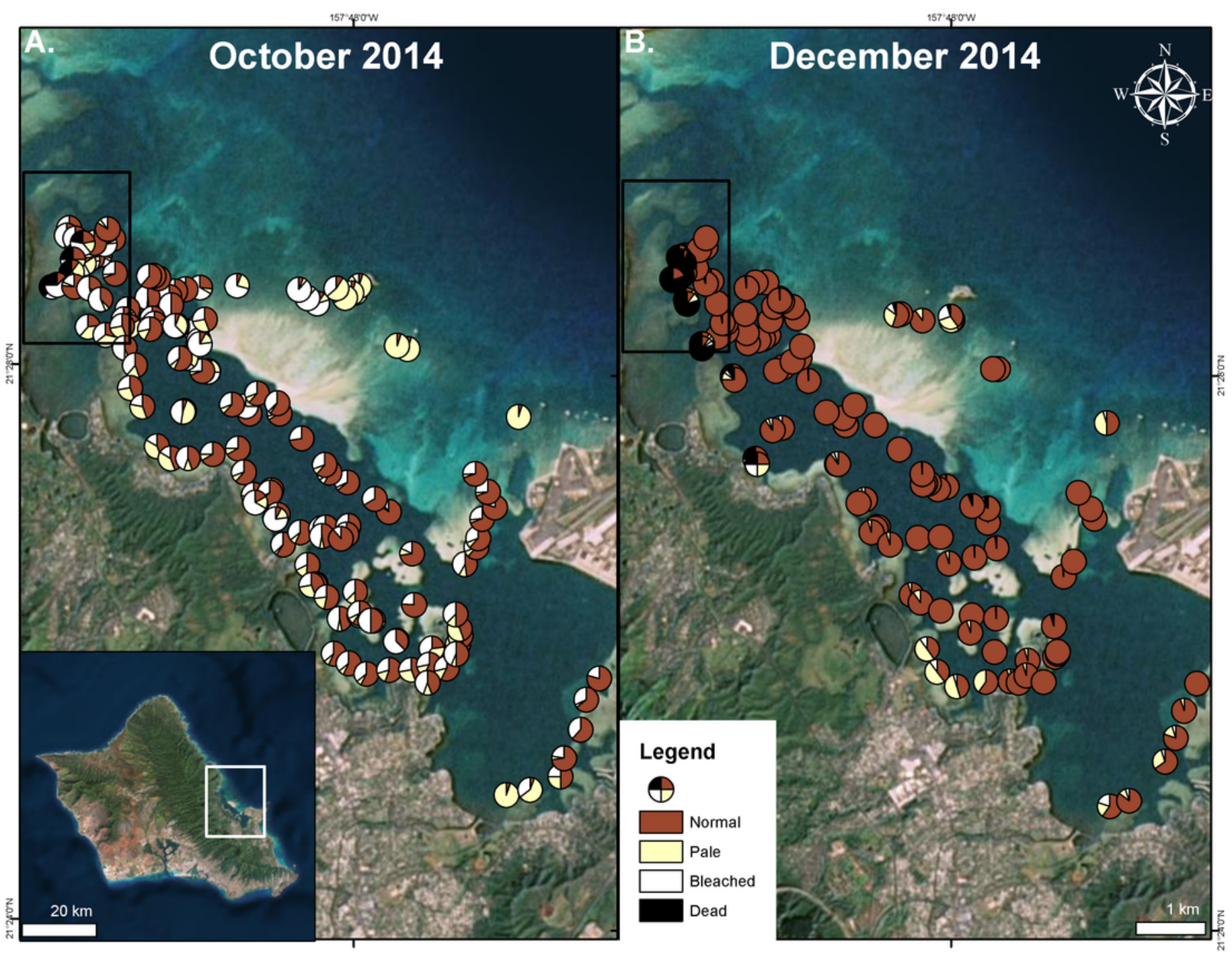


4

Long term Sea surface temperatures (SST)

Combined SST record using IGOSS-NMC temperature data (1992-2014) and corrected NMFS data for Koko Head, O‘ahu (1956 to 1992).

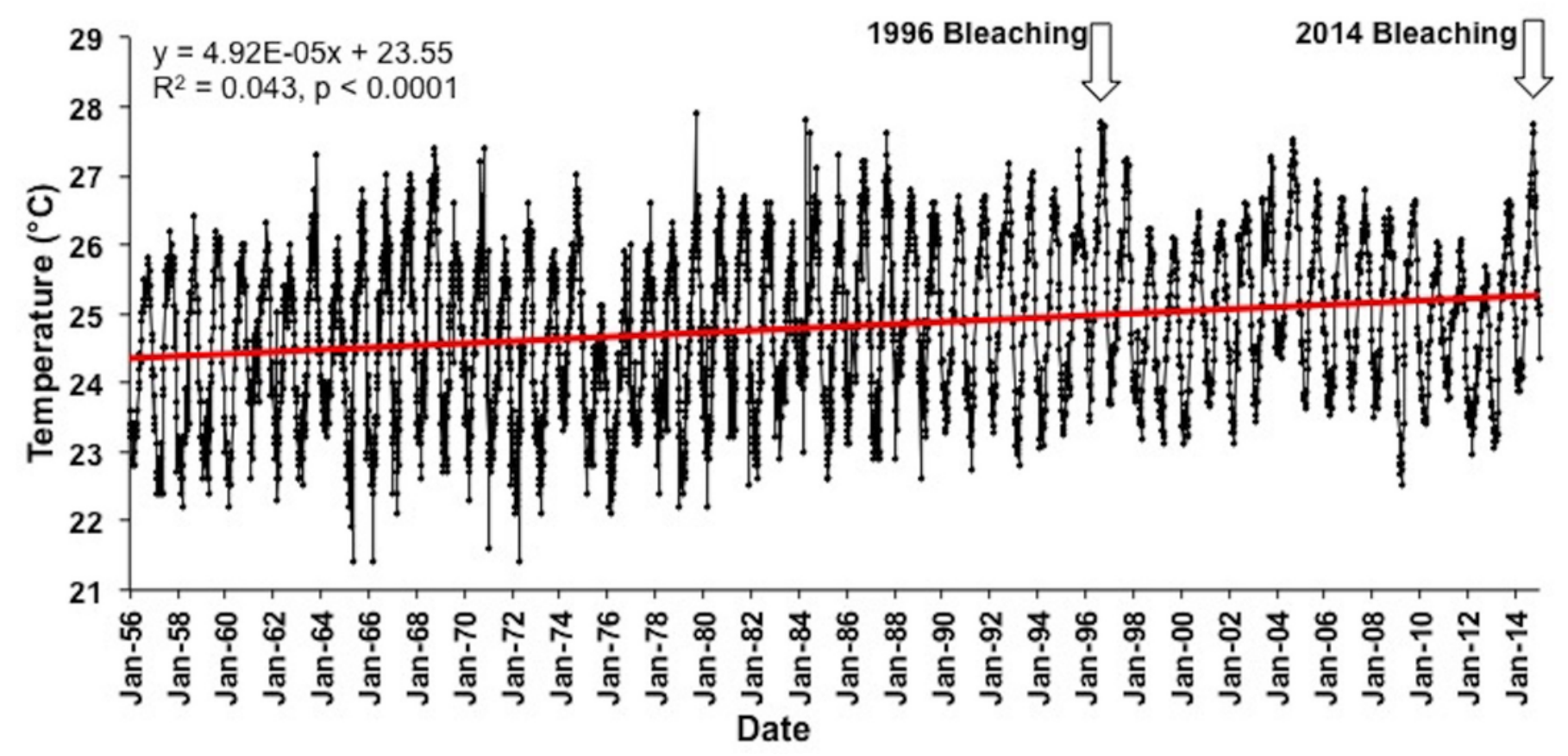


5

Comparison of temperature during the 1996 and 2014 bleaching events

Comparisons of the summer water temperatures during the 1996 (blue) and 2014 (red) bleaching events. Time of initial reports of bleaching for each event are indicated by respective arrow.

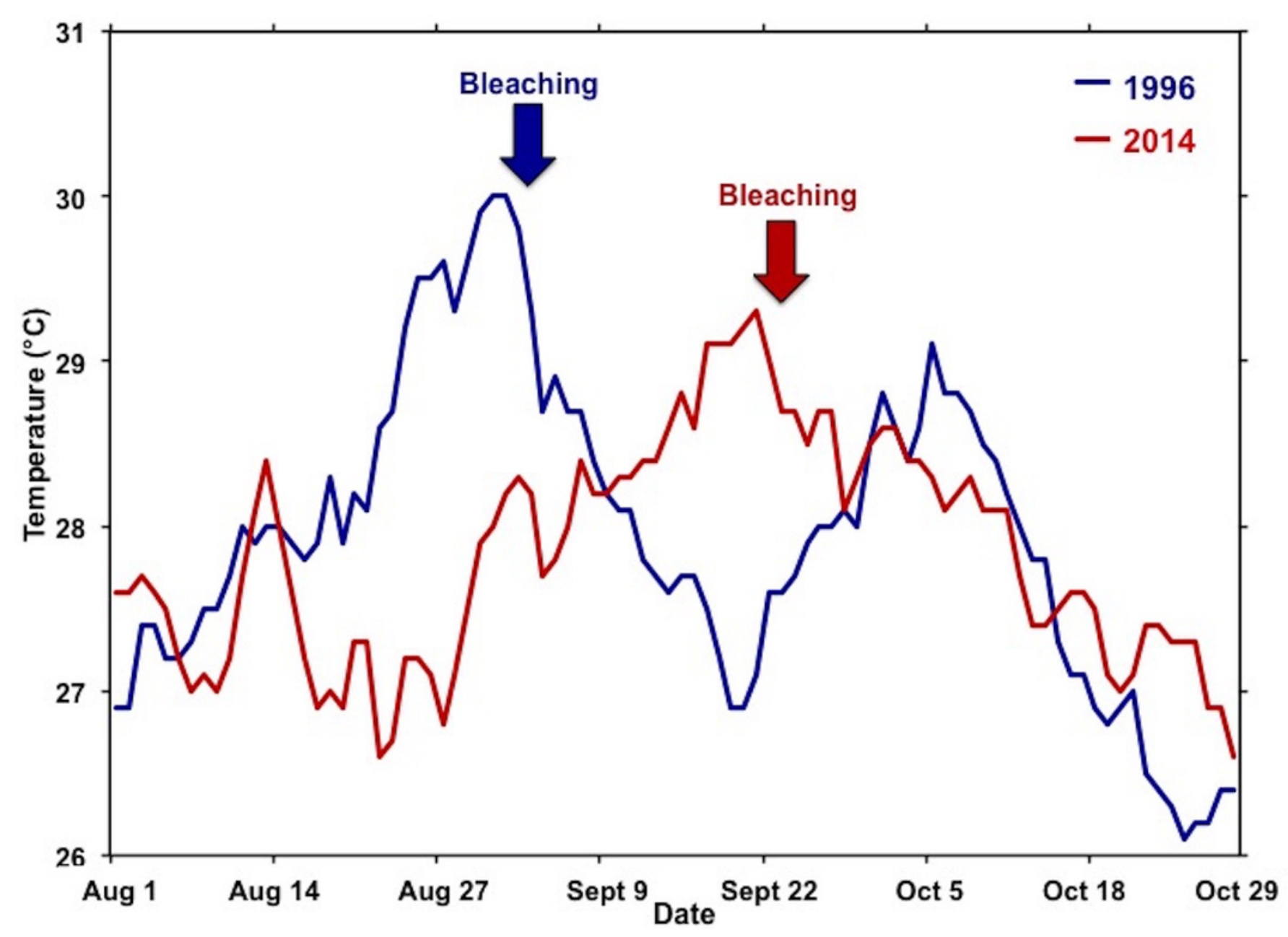

